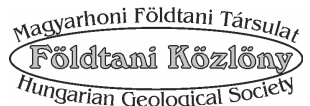

151/4, 411-422., Budapest, 2021

DOI: 10.23928/foldt.kozl.2021.151.4.411

\title{
Structural features in the Miocene sediments of the Pécs-Danitzpuszta sand pit (SW Hungary)
}

\author{
SEBE, Krisztina \\ University of Pécs, Dept. of Geology and Meteorology, 7624 Pécs, Ifjúság útja 6., Hungary; sebe@ gamma.ttk.pte.hu
}

\section{A pécs-danitzpusztai homokbánya miocén üledékeinek szerkezeti elemei}

Összefoglalás

A pécs-danitzpusztai homokbánya a Mecsek hegységperemi vetőzónája mentén fekszik, középső és felső miocén (badeni-pannóniai) üledékeket tár fel. Az erősen tektonizált rétegsor kora pannóniai és annál fiatalabb deformációk nyomait ôrzi, amelyeket más feltárásban nem tanulmányozhatunk. Jelen cikkben több mint húsz év megfigyeléseit foglaljuk össze, a deformációs események korát puhatestú-rétegtan segítségével határoljuk be, és ezek alapján következtetünk a terület szerkezetalakulására. A 10,2-10,0 millió évvel ezelőtti időszak elején ÉÉNy-DDK-i irányú extenzió (transztenzió) hatására normálvetők, árokszerkezetek, negatív virágszerkezetek képződtek. Arra mutatnak, hogy a litoszféra-megnyúláshoz kapcsolódó vetőmúködés még a késô miocénben is zajlott, bár kérdéses, hogy ez a deformációs esemény a Pannon-medence geodinamikai fejlődéstörténetében a szin- vagy a poszt-rift fázishoz tartozik-e. Nem sokkal később, még mindig a 10,2-10,0 millió évvel ezelőtti időszak első felében a terület É-D-i vagy ÉÉNy-DDK-i összenyomás alá került. E feszültségmezó hatására feltolódások alakultak ki a pannóniai mészmárgában és homokban, és a teljes középső - felsô miocén üledéksor meggyưrődött, a réteglapok mentén csúszás és a ridegebb kôzetek blokkos elforgása történt. Az éppen leülepedő homok rétegei dél felé vastagodtak, dőlésük folyamatosan változott. A homokon belül szögdiszkordancia alakult ki, képződésében a Pannon-tó vízszintjének változása is közrejátszhatott. A kompressziós eseményt Afrika és Európa közeledésével magyarázhatjuk, de regionálisan nem tudjuk korrelálni, idősebb a medenceinverzióhoz köthető eddig publikált szerkezeti eseményeknél.

Kulcsszavak: Pannon-medence, Mecsek, tektonika, poszt-rift, medenceinverzió

Abstract

The Pécs-Danitzpuszta sand pit in southern Hungary exposes middle and upper Miocene (Badenian to Pannonian/ Langhian to Tortonian) sediments along the mountain front fault zone of the Mecsek Mts and preserves an essential record of tectonic events during and after the early late Miocene, which are not exposed elsewhere in the region. In this paper we present structural observations recorded over 20 years of work, date the deformation events with mollusk biostratigraphy and make inferences on the structural evolution of the area. At the beginning of the time interval between 10.2-10.0 Ma, NNW-SSE (to NW-SE) extension created normal faults and negative flower structures. These show that extension-related fault activity lasted here up to the late Miocene. Shortly thereafter, still in the early part of the time interval between 10.2-10.0 Ma, N-S to NNW-SSE compression ensued and dominated the area ever since. Deformations under this stress field included reverse faulting in the Pannonian marls and sands, folding of the whole succession, with bedding-plane slip and shearing-related block rotation in the already deposited middle and upper Miocene marl layers and continuously changing bedding dips and southward thickening layers in the Pannonian sands. Lake level changes of Lake Pannon must have played a role in the formation of an angular unconformity within the sands besides compression. The compressional event can be explained by the Africa (Adria) - Europe convergence, but cannot be correlated regionally; it pre-dates basin inversion-related events reported from the region so far.

Keywords: Pannonian Basin, Mecsek Mts, tectonics, post-rift, basin inversion 


\section{Introduction}

The Pécs-Danitzpuszta sand pit in southern Hungary exposes sediments from the early history of the late Miocene Pliocene brackish-water Lake Pannon, a descendant of the Central Paratethys. It is located along the SE margin of the Mecsek Mountains and is the most important and bestknown outcrop of the lower part of Pannonian (upper Miocene) deposits in the region, both calcareous marls and limonitic sands. It has long been known for the deformations visible in the sands (VADÁsz 1960), and is a type locality of Lake Pannon sediments in the Mecsek area (KLEB 1973). Because of its large extent, its location along the mountainfront fault zone, and because the exposed rock units represent an age interval hardly accessible elsewhere, it preserves an essential record of tectonic events during and after the early late Miocene.

Although multiple papers mentioned structural features from the sand pit in the past decades (BENKOVICS 1997, Csontos et al. 2002, KonRÁD \& Sebe 2010), they contain a limited amount of observations, and the dating of events carries uncertainties as well. Since then, we have collected numerous structural measurements and observations across the large sand pit. In order to expose structural features in the Pannonian calcareous marls, a $50 \mathrm{~m}$ long trench was excavated in 2018 in the northern part of the sand pit. This created a marvelous exposure, revealing the downward continuation of the sedimentary succession and deformations in the mountain-front fault zone, which cannot be observed with other methods. Moreover, with the advance of mollusk biostratigraphy, it became possible to link numerical ages to Lake Pannon deposits (MAGYAR 2021), and this can be used for a relatively accurate dating of tectonic events as well. This dating is much needed in the fine-tuning of our knowledge about the structural evolution of the Pannonian Basin (FODOR 2019), especially in the eventful Neogene (CsONTOS et al. 1991; FoDOR et al. 1999, 2005; BADA et al. 2007). Here we present structural observations collected in the sand pit in the past $>20$ years and the structural evolution of the area that can be deduced from the observations, with the highest temporal resolution achieved so far.

\section{Geological setting}

The Pécs-Danitzpuszta sand pit lies on the southern boundary fault zone of the Mecsek Mts, the Mecsekalja Fault Zone (Figure 1). It exposes two main lithological units of late Miocene (Pannonian/Tortonian) age: light grey, white or yellowish grey calcareous marls and silts (Endrőd Formation) in the northern wall, and the overlying yellowish brown, coarse limonitic sands (Kálla Member of the Békés Fm.) in the rest of the area (Figure 2). The trench starting from the northern wall of the sand pit exposed Sarmatian and Badenian (Langhian and Serravallian) mixed carbonate and clastic deposits stratigraphically below the Pannonian sediments. The whole succession is strongly tilted, thus younging is dominantly to-

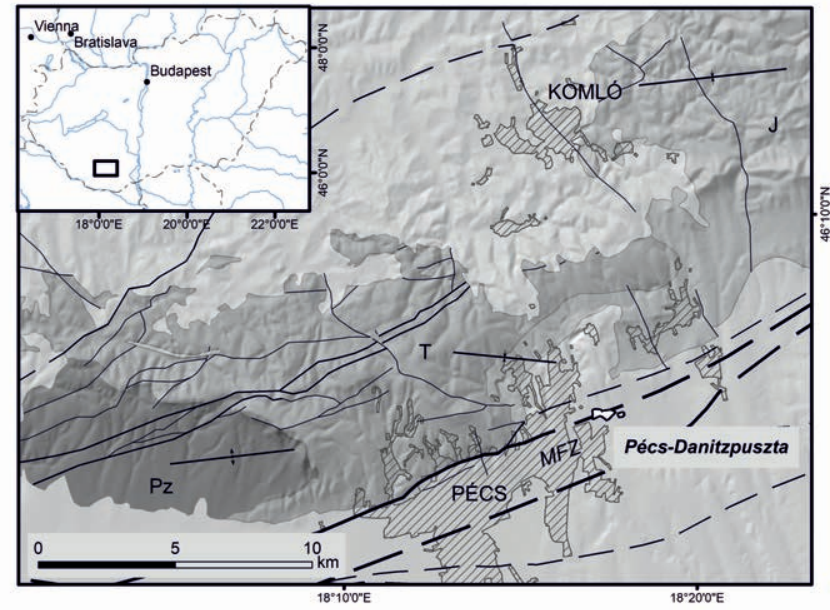

Figure 1. Tectonic setting of the Pécs-Danitzpuszta sand pit. Base map: KoNRÁD et al. (2010)

Legend: Pz: Paleozoic; T: Triassic; J: Jurassic rocks; MFZ: Mecsekalja Fault Zone

1. ábra. A pécs-danitzpusztai homokbánya szerkezeti helyzete. Alaptérkép: KONRÁD et al. (2010)

Jelmagyarázat: Pz: paleozoos, T: triász, J: jura közetek. MFZ: Mecsekalja-öv

wards the south and not upwards. In the western wall, the limonitic sands are divided by an angular unconformity, observed previously in more eastern outcrops, e.g., by VADÁsZ (1960) or KLEB (1973). For a detailed description of the sand pit, see SEBE et al. (2021).

Two deformation events were identified in the sand pit: syn-sedimentary transtension during the deposition of the lowermost part of the sands and syn- to post-sedimentary N-S compression (KonRÁD \& SEBE 2010, Csontos et al. 2002). The tilting of the succession and the different dips were explained with compression-related folding above a blind, south-vergent thrust fault during the late Pannonian (Benkovics 1997, Csontos et al. 2002).

\section{Methods}

Structural measurements were carried out in various parts of the sand pit. Kinematic indicators like slickenlines were measured in the marls. They were absent in the limonitic sands; thus, in these cases the stress orientations are inferred with some uncertainty from MOHR pairs (ANDERSON 1951, FoDOR 2010). Because of the low dip angle and the diffuse bedding planes, bedding dip measurements have uncertainties especially in case of the sand layers above the unconformity and in the uppermost, gently dipping beds below it. Stereoplots are lower hemisphere SCHMIDT projections.

Deformation events were dated by biostratigraphy, mostly by mollusks, based on the endemic species of Lake Pannon (Magyar \& Geary 2012; Sebe \& MAGYar submitted). This provides a resolution on the order of magnitude of $\sim 1 \mathrm{Ma}$. For this, systematic collection of mollusks was carried out in the Pannonian calcareous marls. In the limonitic sands, most mollusks came from the industrial sieving of the sands, they were found in the coarse fraction remaining after sieving. Thus their exact stratigraphic position was usually 


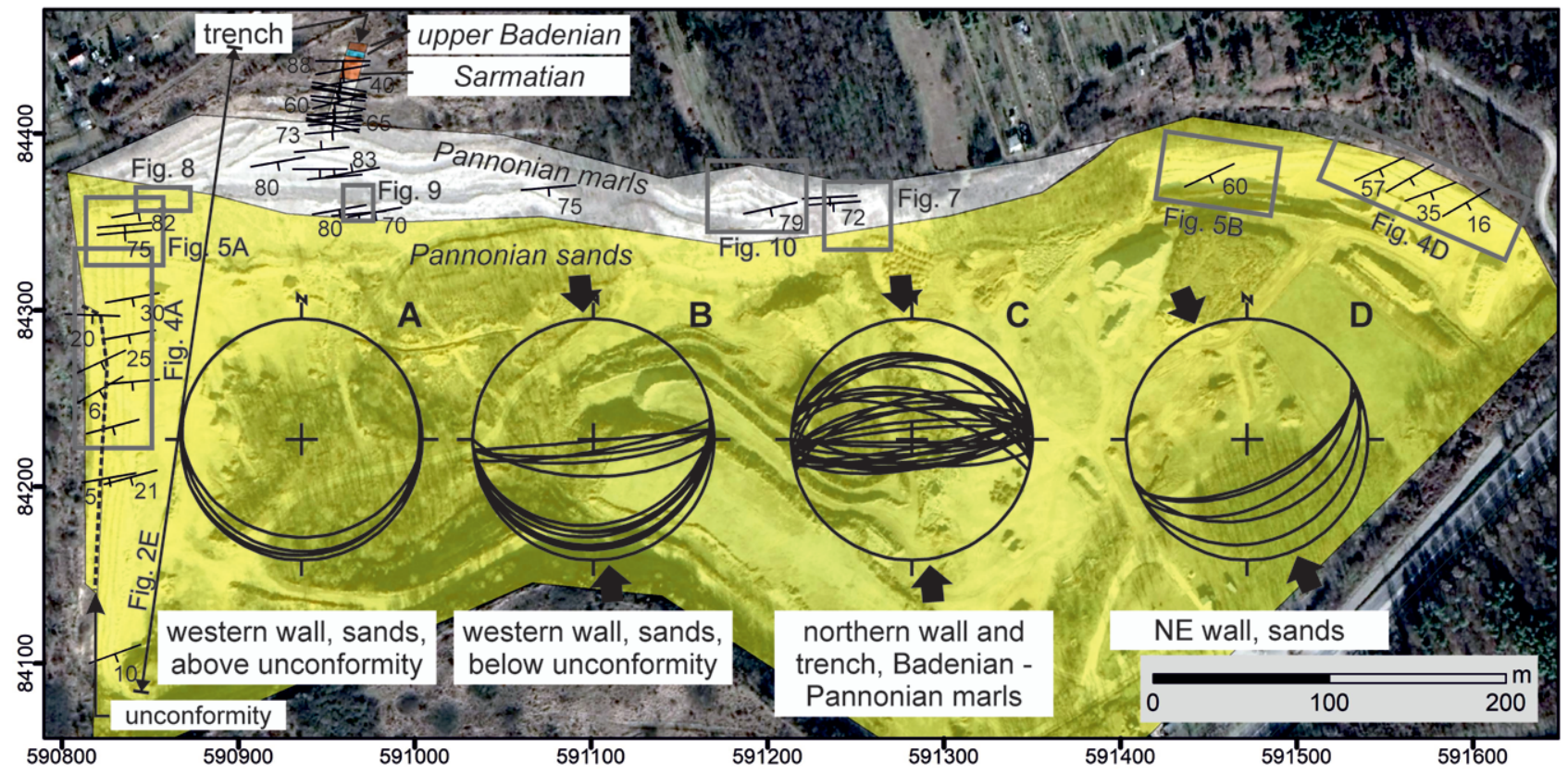

E

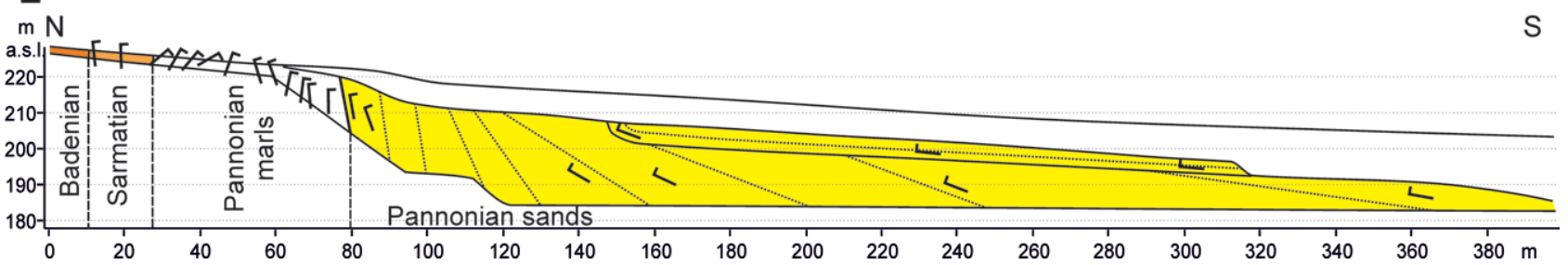

Figure 2. Stratigraphic units and bedding dips in the sand pit. All northerly dips belong to overturned beds. Marks in the cross-section indicate true dip angles 2. ábra. A bányában észlelt rétegtani egységek és rétegdölések. Az északias dőlések átbuktatott rétegek dölései. A szelvény jelei a valódi dölésszögeket mutatják

unknown, it could only be confined to a relatively large portion of the wall being extracted at the given time. We therefore executed collecting campaigns targeted for tectonically interesting parts of the sand pit, e.g., above the unconformity or at the very base of the sands.

\section{Results}

\section{Bedding dips}

The older, northern part of the succession - the Sarmatian deposits and most of the upper Miocene calcareous marls - is dominantly overturned, with varying dip angles (Figure 2E). Bedding dip then decreases within the upper part of the Pannonian marls, i.e., it approaches the vertical in the southern end of the trench (Figure 3). The marl/sand boundary within the Pannonian succession is vertical or subvertical, though both its dip angle and dip direction vary along strike. Bedding dip returns to normal in the Pannonian sands and decreases continuously towards the south, i.e., upsection, to $\sim 15^{\circ}$, observable both in the western and northeastern wall of the sand pit. This succession with the continuously changing dip angles is truncated by a sharp angular unconformity, visible in the western wall, and is overlain by nearly horizontal sand layers of the same lithology
(Figure 3, Figure 4A). Dip directions scatter around SSE for layers with normal dip and $\mathrm{N}-\mathrm{NNW}$ for overturned beds (Figure 2).

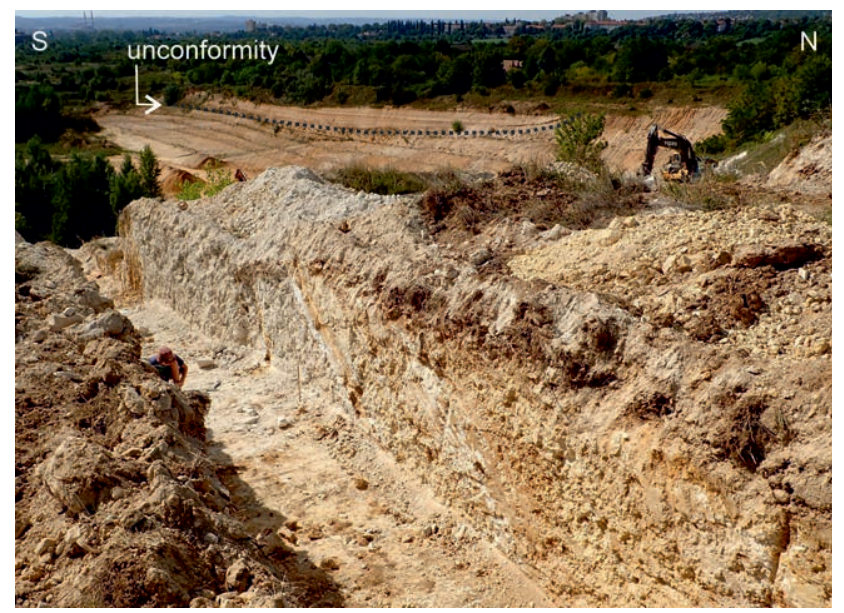

Figure 3. Northward-dipping, overturned Pannonian calcareous marls in the trench (foreground), and south-dipping sands in the western wall of the sand pit (background). Photo taken along the trench, looking southwest. Western wall pictured in the top of the photo (cf., map of Figure 2)

3. ábra. Észak felédölö, átbuktatott pannóniai mészmárgaösszlet a kutatóárokban (elötérben) és délre dölö homokrétegek a bánya nyugati falában (háttérben). A kép az árok mentén készült, DNy felé nézve. A bánya nyugati fala a kép felsö részén látható (a feltárások elhelyezkedését l. a 2. ábrán) 

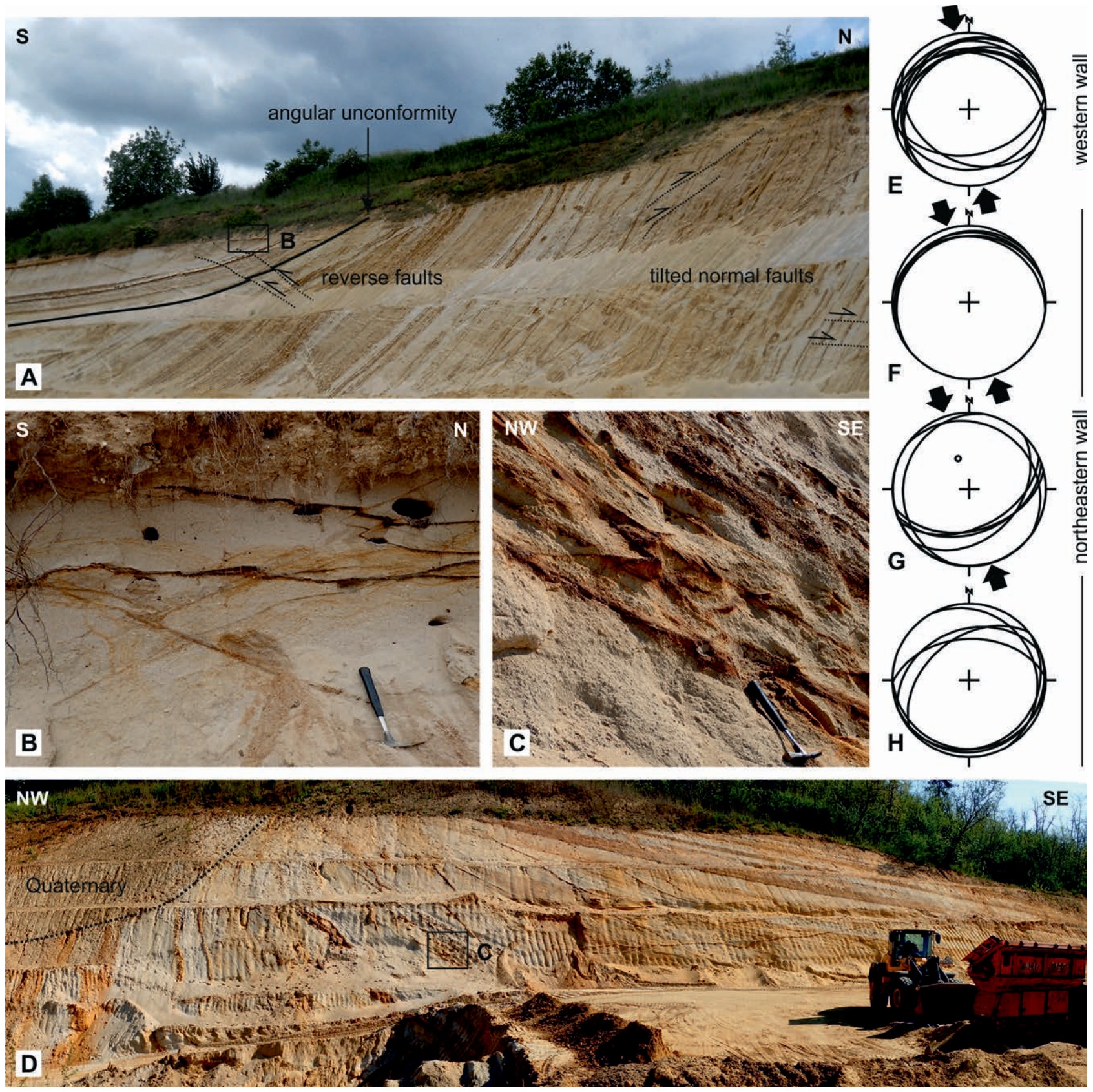

Figure 4. Structural features in the sands. A) Changing dip angle and angular unconformity in the western wall in 2016; B) reverse faults in the western wall displacing dark limonitic bands (2021); C) tilted reverse faults in the NE wall highlighted by the displaced limonite banding (2020); D) changing dip angle in the NE wall (2020); E-H) stereoplots of reverse faults: western wall (E), post-tilt faults of NE wall (F), syn-tilt faults of the NE wall in Fig. C, with pole of local bedding $\operatorname{dip}(\mathrm{G})$, the latter backtilted with bedding $(\mathrm{H})$

4. ábra. Szerkezeti elemek a pannóniai homokösszletben. A) Változó rétegdölés és szögdiszkordancia a nyugati falban 2016-ban; B) vastag limonitsávokat elvetô feltolódások a nyugati falban (2021); C) limonitosodás miatt kipreparálódott kibillent feltolódások az ÉK-i falban (2020); D) változó dölésszögü rétegek az ÉK-i falban (2020); E-H) a feltolódások sztereogramjai: nyugati fal (E), az ÉK-i fal billenés utáni vetöi (F), a C kép billenés alatti vetöi az ÉK-i falban, a helyi rétegdölés pólusponttal jelölve $(G)$, valamint ez utóbbiak a rétegdöléssel visszabillentve $(H)$

The trench has revealed that the uppermost $1-2 \mathrm{~m}$ of the steeply dipping layers are dragged downslope by surface processes. In some cases this includes a change in dip direction: e.g., in the Sarmatian and Badenian beds, the dip of the same bed is southerly near the bottom of the trench, while northerly (overturned) in the dragged upper part of the layers (see Figure 5. in Sebe et al., 2021). This resolves the problem that KONRÁD \& SEBE (2010) called attention to, namely that significantly different bedding dips were observed within a dis-

tance of just a few metres $\left(20-30^{\circ}\right.$ northerly and $70^{\circ}$ southerly dip within $10 \mathrm{~m}$ ). The trench revealed that there is no fault between the differently dipping layers; it is surface drag (slope creep) that caused the difference in the dips. This also means that dip angles recorded in small surface outcrops should be handled with caution, even in seemingly in situ, well-layered sediments. Because of the near-surface deformation, bedding dips in the trench were measured at the deepest possible location along a given bed. 

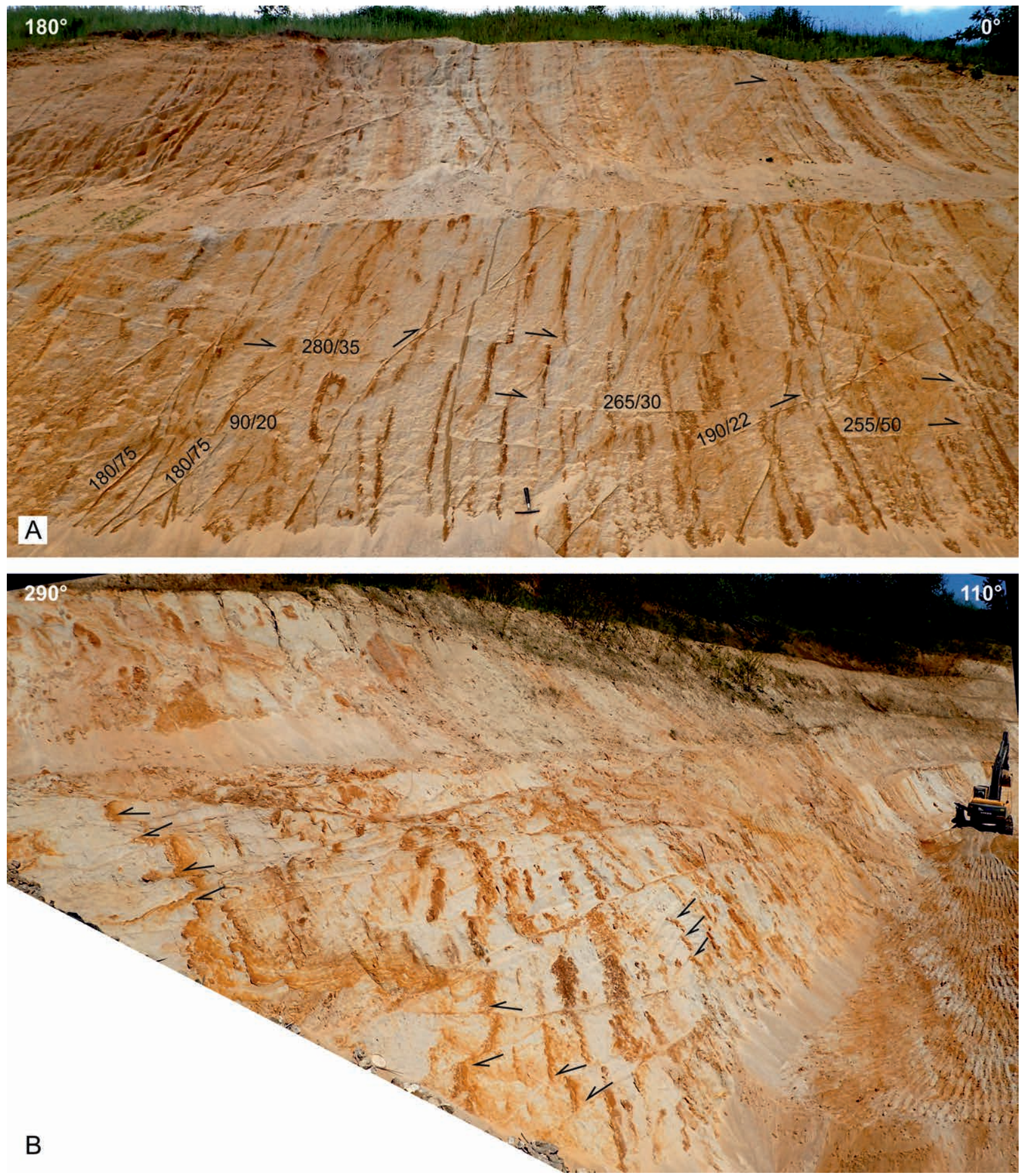

Figure 5. Syn-sedimentary normal fault arrays in sands. A) Northern end of the western wall, 2016. Bedding dips are all $80-70^{\circ}$ to the south $($ Figure $2 B)$, the beds in the right side of the image appear overturned only because of the wide viewing angle. Stereoplots in Figure 6A. B) Eastern end of the northern wall, 2020. Note that the photo was taken oblique to the wall, approximately in strike direction of the layers. Stereoplots in Figure $6 E$

5. ábra. Üledékképzödéssel egyidejü normálvetó-rajok a homokban. A) A Ny-i fal északi vége 2016-ban. A rétegdölés végig délies, 70-80 körüli, a kép jobb oldalán a rétegek csak a széles látószög miatt tünnek átbuktatottnak. A vetök sztereogramja a 6A ábrán látható. B) Az északi fal K-i vége 2020-ban. A fénykép nem a falra merölegesen, hanem ferde szögben, a rétegek csapásirányában készült. Sztereogram a 6E ábrán

\section{Normal faults}

Arrays of originally normal faults, both antithetic and synthetic, were recorded in the uppermost few metres of the calcareous marls (in the transitional interval towards the sands, composed of marls and calcareous silts) and in the lowermost 15-20 m of the sands. An example just above the marl/sand boundary was shown by KonRÁD \& SEBE (2010) (Figure 6C). The deeper parts of the succession have not been exposed in large surfaces, so faults, even if existent, 

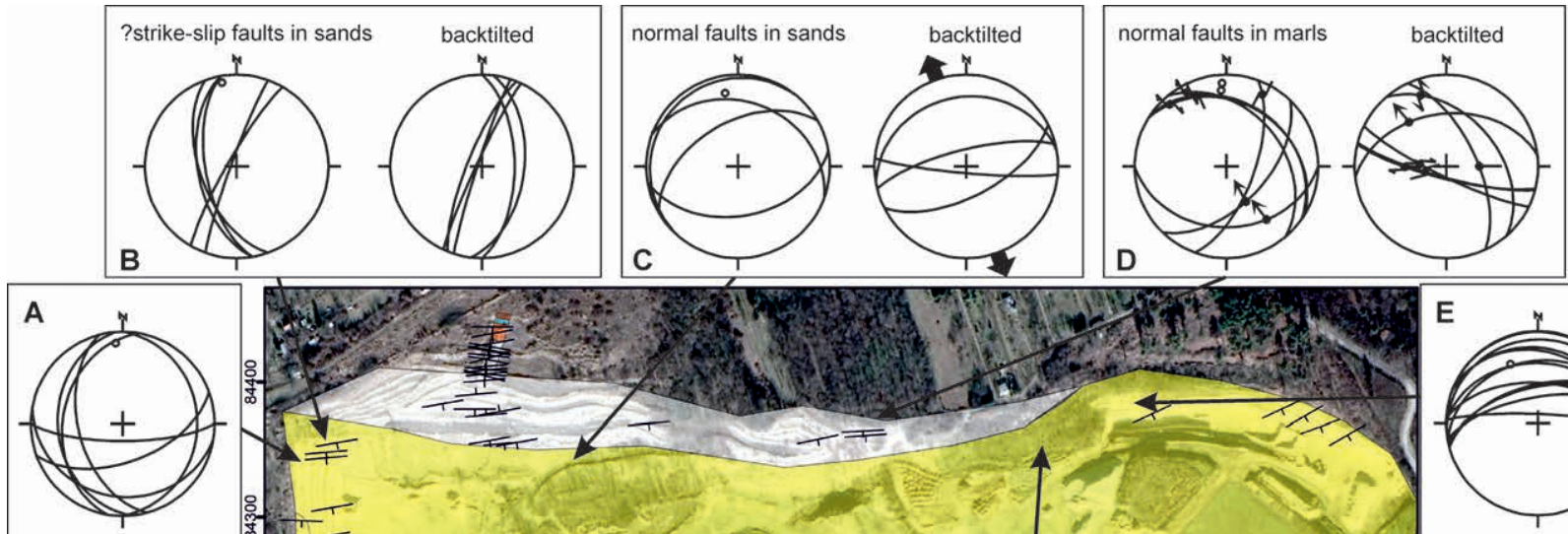

normal faults in sands

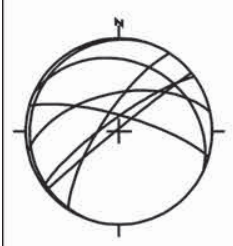

backtilted

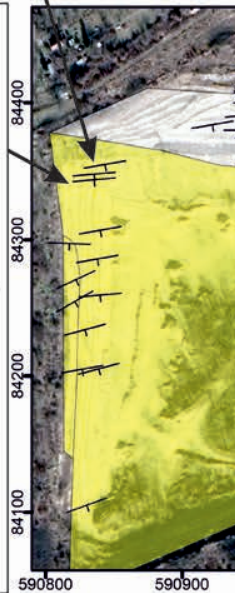

D

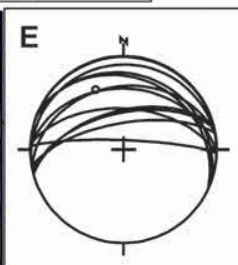

normal faults in sands

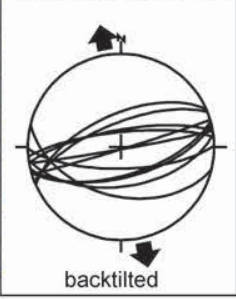

Figure 6. Spatial orientation of normal and strike-slip faults

6. ábra. A normálvetők és eltolódások térbeli helyzete

could go unnoticed. The fault arrays occur in subvertical layers and thus appear mostly as reverse faults today, but their geometries and their orientation relative to bedding suggest that they formed as faults with normal component before the tilting of the succession. Therefore, their present dip data were backtilted with the local bedding dips to investigate their original orientation.

Faults in the sands are distributed at a few tens of $\mathrm{cm}$ from each other and have displacements of a few tens of $\mathrm{cm}$ (Figure 5). Strictly speaking, all types of faults in the sands are deformation bands; however, for the sake of simplicity, we refer to them as faults. As bed boundaries in the sand are uneven and rather diffuse, it is hard to say if beds systematically thicken along one side of a certain fault. Nevertheless, the faults, which have relatively low dip angles today, die out and are sealed upwards, suggesting syn-sedimentary movement. The sense of movement was mostly normal in these cases, but also some reverse slips occur.

If backtilted with the local bedding dip, the faults have ENE-WSW or NE-SW strikes and their dips reach relatively steep angles, close to vertical (Figure 6A, $C, E$ ). In the NE wall, the faults now appear as north-dipping reverse faults, but their dip angles show too large scatter (Figure 5B, Figure $6 E$ ). If backtilted with the local bedding, their orientations give a symmetrical pattern typical of fault arrays with normal component (Figure 6E). The backtilted pattern is similar for the centre of the northern wall (Figure 6C). Slickenlines are not preserved in the coarse sands, but the relatively steep dip angles and occasionally opposite (inverse instead of normal) movement directions of some faults refer to oblique - normal plus strike-slip - movement of the fault arrays. So do flower structures like the one shown by KLEB
(1973, figure 19). In the western wall, gently west- and eastdipping faults show dominantly strike-slip displacement today (Figure 5A); if backtilted, most of them become normal faults as well, with strikes similar to the previous two locations (Figure 6A). Differently oriented further faults in this wall may point to multiple deformation events. Less steep south-dipping faults might have formed as reverse faults as well during the tilting (folding) of the succession.

In the uppermost part of the marls, faults with originally normal component appear at varying distances from each other (Figure 7). At present, single faults could also be interpreted as reverse faults, but their convergence and merging downsection (towards older layers) (Figure $7 B$ ) indicates that they belong to normal fault sets. They often crosscut only a few layers (Figure 7A), sometimes they form antithetic pairs. Although in cross-section they appear as normal faults, slickenlines indicate oblique, dominantly strike-slip displacement (Figure 6D).

Faults with normal component are restricted to a relatively small interval of the sedimentary succession, and this evokes the conclusion that they formed during the same deformation event, in the same stress field. The features pointing to normal displacement indicate that they were created before the tilting of the succession. Besides being syn-sedimentary, relatively short normal faults - crosscutting only a limited number of layers - can also form along fold hinges due to local stretching (fold-accommodation faults), in a buried position. It cannot be excluded that normal faults around the marl/sand boundary were created this way during the folding of the succession. The asymmetry of some fault groups in backtilted position (e.g., in the marls, Figure $6 D$ and Figure $7 B$ ) may refer to compression-related (syn-tilt) 

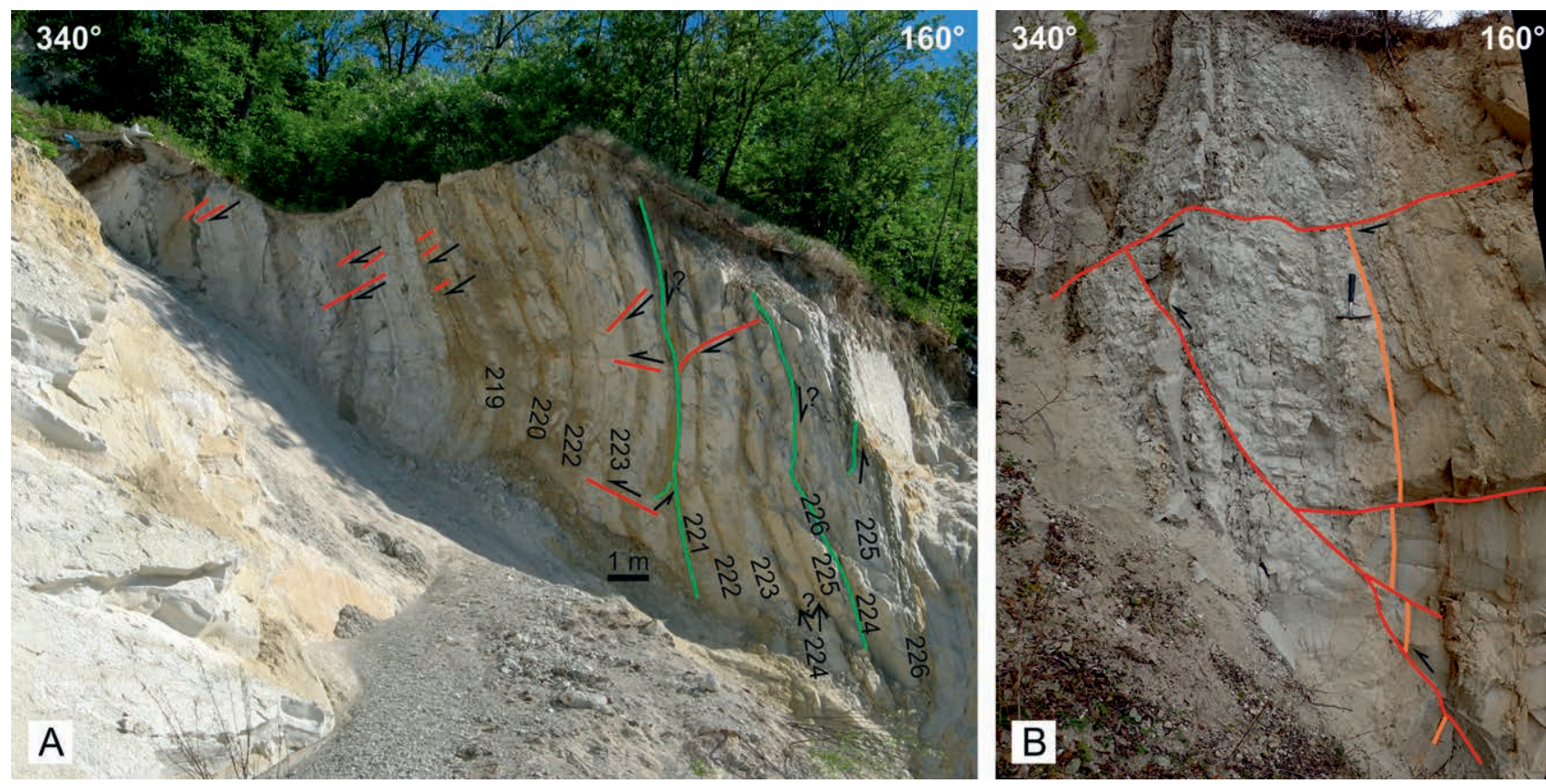

Figure 7. Tilted normal faults (light red) and post-sedimentary thrusts between repeated layer packages (green, partly along bedding planes) in marls and silts. A) Central part of northern wall, 2015. B) Detail of a parallel outcrop $\sim 40 \mathrm{~m}$ to the west, 2020; hammer for scale. The sense of thrusts (whether originally northor south-vergent) could not be identified

7. ábra. Kibillent normálvetők (pirossal jelölve) és ismétlödő rétegcsoportok közti későbbi feltolódások (zöld, részben réteglapok mentén) a pannóniai mészmárgasorozat felsö részében. A) Feltárás az északi fal középső részén 2015-ben. B) Az elözőtöl nyugatra kb. 40 m-re húzódó párhuzamos feltárás részlete, 2020. Nem volt megállapitható, hogy a feltolódások eredetileg észak vagy dél felé mozogtak

formation. No obvious bed thickening could be observed in the succession along faults, which could be decisive in this case. However, the appearance of normal faults in a concave curvature, like the one above the $1 \mathrm{~m}$ sign in Figure $7 \mathrm{~A}$, point to syn-sedimentary movement.

Despite the narrow stratigraphic range of the normal faults, their original, backtilted orientations show quite large scatter even in this relatively small area (Figure 6). This does not necessarily mean that they were created during separate deformation events. An explanation for this may be the different competence of the marls and the sands. Another factor that complicates the picture is that the sand pit lies on the front of a basement block projecting south from the main body of the mountains, between the Pécsbánya embayment in the west and the mountain foreland in the east (Figure 1). This geometry caused different folding (tilting) directions in the Neogene sediments around the basement block, the strike orientations of tilted beds show an arcuate pattern (Figure 2). Although the backtilting of earlier faults with the local bedding dips should eliminate the effect of different folding directions, the irregular mountain front geometry still could have caused locally varying orientations of earlier fault groups as well. This setting warns us not to differentiate too many deformation events based on small differences in fault orientations.

\section{Strike-slip? faults}

In the western corner of the northern wall, steep, subparallel faults with westerly dips were observed (Figure 8,
Figure $6 B$ ). Their apparent displacements attain a maximum of a few tens of $\mathrm{cm}$. Some of them have normal, some others reverse sense; this may refer to strike-slip movement for the whole fault array. It is uncertain which fault group and deformation event they belong to. They are located very close to the tilted normal faults of the western wall, but they have different orientations (Figure 6). In case these two fault groups are coeval, the strike-slip faults could have acted as tear faults between normal ones. They could have formed posterior to tilting as well, but their orientation does not fit into a common stress field with the reverse faults.

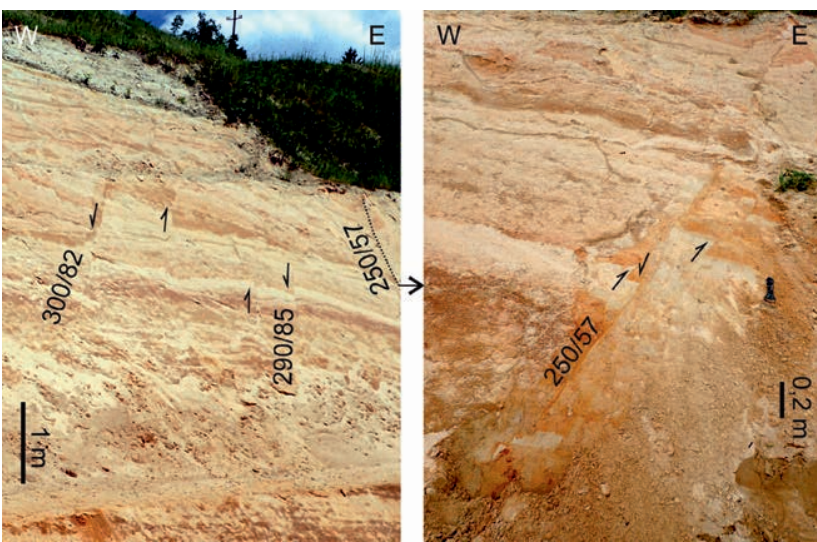

Figure 8. Possible strike-slip faults near the western end of the northern wall. Stereoplots in Figure $6 A$. Note the varying apparent reverse and normal separation along the set

8. ábra. Valószínü eltolódások az északi fal nyugati végében, változó irányu látszólagos elvetéssel. Sztereogram a 6 . A ábrán 


\section{Reverse faults}

Reverse faults were observed in the Pannonian deposits, both in marls and sands. Their size is variable, the smallest ones crosscut only a few layers, while the largest ones displace sediment packages with tens of metres of thickness.

Small faults can be observed in the Pannonian calcareous marls, which crosscut layers and often terminate at bedding planes (Figure 9). They appear as normal faults in their present position, in the subvertical marl layers. However, the rounded shape of the striations ("soft striae") refers to an early formation of the faults, before the complete lithification of the deposit. If backtilted with the local bedding dip (170/80), they point to SSE-vergent thrusting. A minor sinistral component is indicated by the slickenlines. No tensional features have been observed that post-date the largescale folding and tilting of the succession, and the backtilted orientation of the studied faults fits the compression direction for the area, so they are most probably reverse faults that formed at the onset of shortening, before the folding of the succession.

Reverse faults crosscut the sands both in the western and in the northeastern wall of the sand pit (Figure 4). They occur at irregular intervals. Due to the lack of slickenlines, it is not possible to measure the exact slip direction along them; their visible displacement is usually only a few tens of $\mathrm{cm}$. Most of the reverse faults must have formed when the layers had already reached their present-day (tilted) position. There was a group of reverse faults in the NE wall that enclose acute angles $\left(20-30^{\circ}\right)$ with the bedding (Figure $4 C$, G). If completely backtilted with the bedding, their orientation is still asymmetric (Figure $4 H$ ). They become symmetrical at an intermediate stage of tilting between the original and the present bedding dip; thus, these can be syn-tilt features.

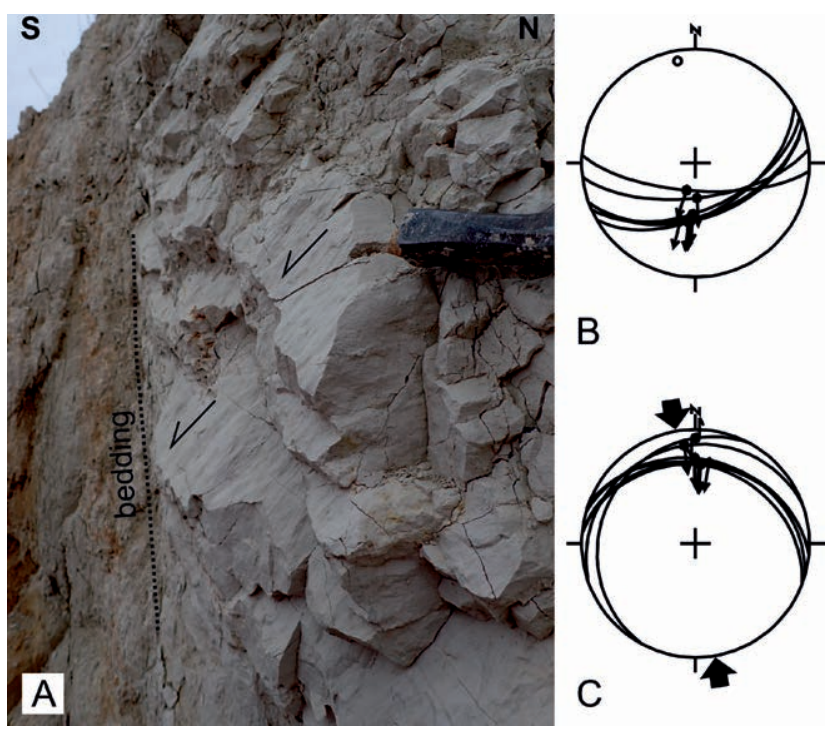

Figure 9. Small faults in the calcareous marls. A) Field photo of the originally reverse, now tilted faults; B) their orientation in stereoplot; C) orientation backtilted to supposed original position

9. ábra. Kis vetők mészmárgában. A) Az eredetileg rátolódásos, kibillent vetők terepi képe; B) sztereogramjuk; C) visszabillentett, eredeti helyzetük sztereogramja
The upper part of the Pannonian marls seems to be most affected by reverse faulting. In most cases outcrop conditions did not allow us to follow the exact trace of faults, but it was possible to notice displacement or repetition of layers. Slip planes often include bedding planes along parts of their lengths (Figure 7, Figure 10B). A few $\mathrm{m}$ thick intervals were observed to be repeated in the uppermost marl and silt layers, where slip happened mostly along bedding planes (Figure $7)$. The vergency of thrusting - whether originally north- or south-vergent - could not be identified. Differences in the thickness and the number of beds in the sedimentary succession at various locations in the sand pit also refer to partly bedding-parallel thrusting. The interval between a tuff layer (205 according to bed numbering in SEBE et al. 2021) and the transitional, yellowish marl and calcareous silt interval capping the "white marls" (from layer 218) is $9 \mathrm{~m}$ thick in the centre of the sand pit, and includes two green clay - sand green clay packages (Figure 10A). It is only $5.5 \mathrm{~m}$ thick in the NW part, with one clay-sand-clay package and another clay layer missing there. In the seemingly conformable succession brecciated intervals occur from place to place, and apparently continuous and undisturbed layers may change their thickness or disappear along strike (Figure 10A). A major thrust fault was exposed by excavations in the central part of the sand pit in 2012, along which a wedge-like body of the succession is repeated (Figure 10A (background) and $C$, marked with arrows). The fault plane has a dip of approximately $60^{\circ}$ towards the SE in its present orientation, while backtilting with local bedding dip gives an original dip towards the NE at the time of its formation. Drag of layers along the plane indicates presently top-to-SE normal, originally SW-vergent reverse movement.

\section{Folds}

Folds are not widespread in the sand pit, but some features point to large-scale folding. Bedding dips in the entire sand pit give the general view of a large south-vergent asymmetrical anticline, with its southern, subvertical limb making up the northern wall of the sand pit, and a connected syncline within the sand pit, with its lower, subhorizontal limb lying below and to the south of the sand pit (Figure 2E, Figure $11 C$ ). This picture is in accord with the model proposed by Csontos et al. (2002). The fold axis is somewhat curved, as shown by the laterally changing strike of the layers (Figure 2). The fold amplitude must exceed $100 \mathrm{~m}$; thus, the curvature of the layers is rarely visible in outcrops of limited size. One such location is in the northern wall, where landslides exposed vertically more extensive outcrops than elsewhere, making the arcuate shape of the calcareous marl layers visible (Figure 7). Here only a small section of the fold is exposed, thus the fold can be either an overturned or a recumbent one; it is not possible to exactly assess the position of the axial plane. The dip of the steep sand layers in the western wall also somewhat increases upwards.

In the trench the lower part of the Pannonian marls and the upper Sarmatian deposits have diverse lithologies. These 

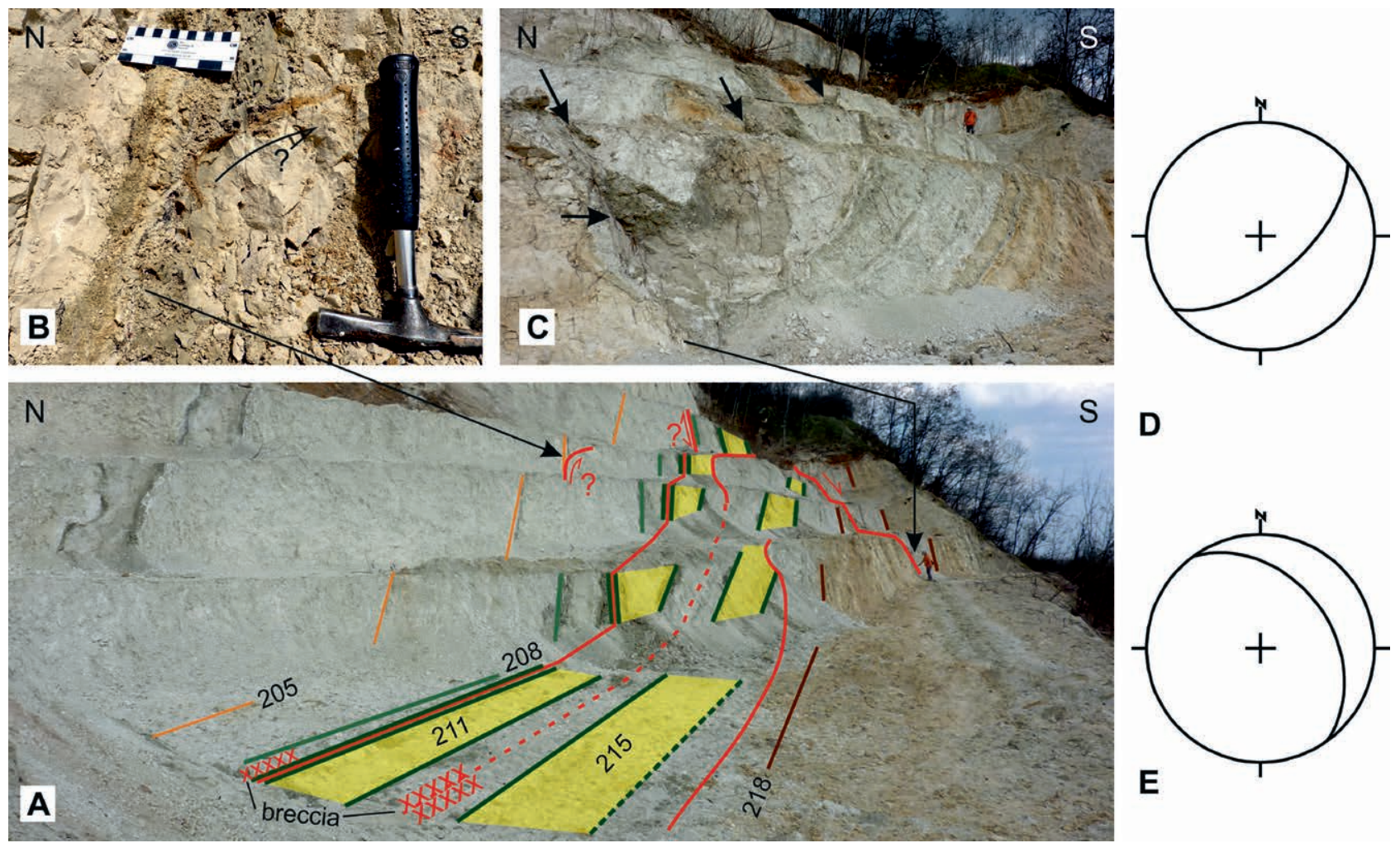

S D

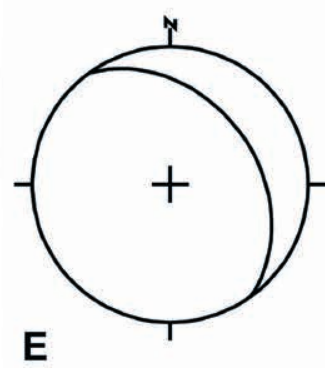

Figure 10. Reverse faults in Pannonian calcareous marls and silts in the central part of the northern wall (A, C: 2012; B: 2016). In fig. C, arrows indicate the location of thrust plane. D) Stereoplot of the major fault plane marked with arrows in A and C. E) The same, backtilted with local bedding dip

10. ábra. Rátolódások a pannóniai mészmárgaösszlet tetejében az északi fal középsỏ részén (A, C: 2012; B: 2016). A Cábrán a nyilak a rátolódási sík helyét mutatják. D) Az A és Cábra nagy, nyillal jelölt vetösíkjának sztereogramja. E) Ugyanez a helyi rétegdöléssel visszabillentve

preserved signs of bedding-plane shearing, which can be related to folding (Figure 11A). Where a competent rock type (hard calcareous marl or limestone) was enclosed by incompetent, soft layers (clays, clay marls), it became dissected by fractures. The produced dominoes got rotated, and the rotation direction is opposite to what would be produced by simple southward thrusting (Figure 11B). Instead, it speaks for flexural slip along bedding planes in a fold limb (Figure 11C).

Folding is visible in the sands as well (Figure 3, Figure 4). In the western wall, the same sand layers become somewhat
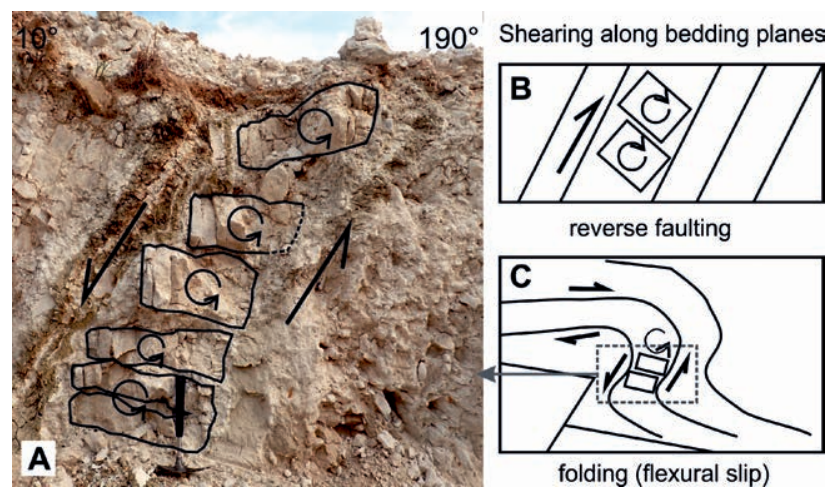

reverse faulting

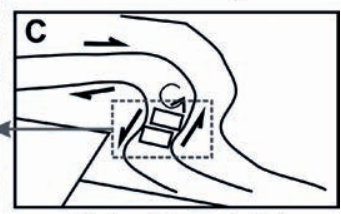

folding (flexural slip)

Figure 11. A) Rotated limestone dominoes between clay and marl layers in the eastern wall of the trench; B-C) possible models to explain their formation

11. ábra. Mészkôréteg nyirás hatására elfordult darabjai agyag-és márgarétegek közt a kutatóárok keleti falában; $B$-C) keletkezésük lehetséges magyarázatának modellje steeper upwards, i.e., they seem to be gently folded. The northern end of the unconformity surface within the sands is also bent upward, indicating that the uplift and southward thrusting of the hanging wall and the induced folding continued after the formation of the unconformity.

Some previous fold observations need to be reevaluated based on the new observations. The "fold with subvertical axis and several tens of metres of radius" reported by KoNRÁD \& SEBE (2010) is now interpreted to have been produced by mining-related landsliding, and the "heavily folded calcareous marl layer in green clay" within the same structure is now explained by pedogenic precipitation instead of deformation.

\section{Discussion}

\section{Deformation events}

The observed structural features can be arranged in chronological order, and they define several deformation events.

\section{Pre-tilt features}

The earliest event happened before the tilting and folding of the sediments and is represented by the observed normal fault sets in the marls and sands (Figures 5, 6, 7) and the negative flower structure of KLEB (1973, fig. 19) in the sands. These features indicate syn-sedimentary transtension, which 
ceased shortly after the onset of sand accumulation. Based on fault orientations, the main extension direction is estimated to be NNW-SSE to NW-SE. Tentatively, strike-slip faults in the sands (Figure 8) can also be assigned to this event.

A part of the shortening-related structures also pre-dates tilting, namely reverse faults in the marls (Figure 9). These can be linked to the start of compression (already during sand deposition), with NNW-SSE shortening.

\section{Syn-tilt features}

The majority of structures in the sand pit is connected to the large-scale syn-sedimentary compressional deformation of the deposits and fit the model of folding above a blind, south-vergent thrust fault proposed based on scarce data by BenKovics (1997) and Csontos et al. (2002). Bedding dip directions and reverse fault orientations refer to $\mathrm{N}-\mathrm{S}$ or NNW-SSE compression during deformation. Folding of the succession caused bedding-plane slip and shearing-related block rotation in the already deposited marl layers (Figures 7, 11), while the sand layers accumulating during that time acquired gradually changing bedding dips and tapering shapes, thickening towards the south (Figures 2, 3). In the sands some reverse faults formed during the folding process and were then further tilted together with the sediments (Figure $4 C, G, H$ ). Erosional truncation of the folded succession produced a sharp unconformity surface in the sands. This angular unconformity can be correlated with the one photographed by VADÁsZ (1960, p. 255), BARTHA (1971, p. 144) and JuHÁsZ (1987, unpaginated table after p. 336). Considering the areal extent of the sand pit at that time, the photos were likely taken in the eastern third of the presentday sand pit. The unconformity thus can be followed for approximately $500 \mathrm{~m}$ in the $\mathrm{E}-\mathrm{W}$ direction. As this surface is overlain by the same lacustrine sands that make up the succession below the surface, i.e., subaqueous sedimentation returned, temporary erosion and renewed submergence can be explained at least partly by lake level change and not just by vertical tectonic movements (i.e., lake level fall and rise, or tectonic uplift, then lake level rise). The facts that there are no pedogenic features along the unconformity surface and that the lithofacies of the sands below and above it is identical suggest that emersion and erosional truncation of the lower unit must have been fast.

\section{Post-tilt features}

Folding continued after the renewal of sand deposition, shown by the upward bending of the unconformity surface. Gently north- and south-dipping reverse faults in the sands indicate that $\mathrm{N}-\mathrm{S}$ oriented shortening continued after the layers have reached their present-day dips.

\section{Age of deformations}

BenKovics (1997) and Csontos et al. (2002) placed the shortening between the "lower" and "upper" Pannonian, while KLEB (1973) wrote that the unconformity lies within the "upper Pannonian" sands. Based on new palaeontologi- cal results (BotKA et al. 2021), now the age of deformations can be confined using time-calibrated mollusk biostratigraphy. The mollusk association in the sand refers to the younger part of the Lymnocardium conjungens littoral mollusk biochron (9.6-11.0 Ma; BotKA et al. 2021). The underlying marls are dated into the youngest part of the Lymnocardium schedelianum sublittoral mollusk biochron (11.4510.2 Ma). Therefore, the age of the sands is estimated to 10.2-10.0 Ma (BотKA et al. 2021). Extension could have happened at the beginning of this interval, while compression dominated most of the time afterwards. Folding and related features were syn-sedimentary, i.e., still before 10.0 Ma, somewhat earlier than the dating suggested by CsonTOS et al. (2002) ("late Pannonian"). Post-tilt shortening may have happened any time afterwards.

\section{Geodynamic interpretation}

The interpretation of the described deformation events in a geodynamic framework is rather complex. The observed pre-tilt NW-SE transtension along the Mecsekalja Fault Zone before or around $10 \mathrm{Ma}$ is in accord with the coeval event along the same fault zone deduced by CsonTos et al. (2002, fig. 15) from a nearby geological cross-section at Pécsszabolcs, just west of the Danitzpuszta sand pit. Further observations (SEBE \& MAGYAR, submitted) show that sedimentation during the earliest Pannonian occurred in faultcontrolled subbasins near the mountain fronts in the Mecsek Mts, similarly to the Transdanubian Range (FODOR 2008, FODOR et al. 2021). These could mean that fault-controlled syn-rift extension did not cease in the middle Miocene in the region, as suggested by BALÁzs et al. (2016), but continued into the early late Miocene. Alternatively, the mentioned events may belong already to the post-rift phase, implying that fault activity continued in the region even in this phase generally characterised by thermal subsidence and modest deformation (e.g., HoRvÁTH et al. 2006).

The $\sim \mathrm{N}-\mathrm{S}$ compression driving the progressive tilting, folding, truncation and reverse faulting of the sediments started between 10.2-10.0 Ma, and is again difficult to evaluate. The "post-Sarmatian inversion event" proposed by HoRváth $(1995,2007)$ might fit in time with the Danitzpuszta compression features. This short inversion phase was described to be manifested in a basinwide unconformity, folding and uplift of pre-Pannonian rocks, the erosion of Sarmatian deposits and non-deposition of early Pannonian rocks, and placed in time between the latest Sarmatian and the early Pannonian, 12-9 Ma (HoRvÁtH 1995, 2007; FODOR et al. 1999; HoRvÁTH et al. 2006). It was attributed to the docking/soft collision of the eastward moving basement of the Pannonian Basin onto the European margin when subduction stopped under the Eastern Carpathians and consequently rifting also ceased in the basin (HoRvÁTH 1995, 2007; BALÁzS et al. 2016). In NW Croatia, ToMLJENOVIĆ \& CsONTOS (2001) reported late Sarmatian, prePannonian ( 12-11 Ma) shortening, while Csontos et al. (2002) described folding and erosion at the Sarmatian- 
Pannonian boundary in the northern foreland of the Mecsek Mts. However, observations in the Serbian part of the Pannonian Basin, where compressional structures are lacking near this horizon, speak against a basinwide, contemporaneous inversion event (MATENCO \& RADIVOJEvić 2012). The $10 \mathrm{Ma}$ event at Danitzpuszta is very close in time to the end of the rifting in the Pannonian Basin as proposed by BALÁzS et al. (2016); i.e., the syn-/post-rift boundary. However, the NNW-SSE compression direction in the Mecsek makes it difficult to regard this the "post-Sarmatian inversion event", which was characterised by E-W shortening (FoDOR et al., 1999). Local north-southerly compression (or transpression) could be caused by a right-lateral (constraining) activity of the entire Mecsek transpressive wedge, as proposed for the neotectonic inversion phase due to the Adria push by CsONTos et al. (2002).

The other candidate, neotectonic basin inversion started 2.5-8 Ma years ago in the SW Pannonian Basin based on new data and on published ones re-calibrated using mollusk biostratigraphy (SEBE \& MAGYAR submitted, based on data from TOMLJENOVIĆ \& CsONTOS 2001, FodOR et al. 2005, UHRin et al. 2009, MATEnco \& RAdivojević 2012, SEBE et al. 2020), much later than the deformation documented in the sand pit. Thus, shortening at the Pécs-Danitzpuszta site can be related to the Africa (Adria) - Europe convergence based on the compression direction, but within this process it is difficult to correlate it with other deformation events in the SW part of the Pannonian Basin; it pre-dates the events in the region, which were interpreted to be linked to the onset of neotectonic basin inversion.

\section{Conclusions}

The Pécs-Danitzpuszta sand pit exposed numerous structural features - tilted beds, faults and folds - from an interval of the Neogene sedimentary succession of SW Hungary, which is strongly underrepresented in surface outcrops. The measurement of the features and the examination of their relationships allowed us to discern two closely succeeding deformation events, while the dating of the deformed sediments with mollusk biostratigraphy enabled us to constrain their timing. At the beginning of the time interval between 10.2-10.0 Ma, NNW-SSE extension (transtension) created normal fault sets and negative flower structures and possib- ly strike-slip faults in the Pannonian marls and the lowermost part of the Pannonian sands. Right thereafter, still in the early part of the mentioned time interval, NNW-SSE compression ensued and has continued to dominate the area ever since. Deformations under this stress field started with small-scale reverse faulting in the Pannonian marls. They continued with the folding of the succession, driven by south-vergent thrusting of the mountains towards their southern foreland. Folding created bedding-plane slip and shearing-related block rotation in the already deposited middle and upper Miocene marl layers and continuously varying bedding dips, southward thickening layer shapes and reverse faults in the Pannonian sands. In the formation of an angular unconformity within the sands, lake level changes of Lake Pannon must also have played a role besides compression. Continuing shortening is shown by the bending of the unconformity and additional post-tilt reverse faults.

The observations show that extension- or transtensionrelated fault activity lasted here up to the late Miocene, though its assignment to the syn- or post-rift phase of the geodynamic evolution of the Pannonian Basin is uncertain. The linkage of the following compressional deformation to the post-rift phase or to the late-stage inversion of the basin cannot be confirmed, either. The compressional event cannot be correlated regionally; it pre-dates basin inversion-related events reported from the region so far.

\section{Acknowledgements}

A part of the data was collected in collaboration with Gyula KONRÁD, and some of the ideas were also proposed by him. We are grateful to Béla MoLnÁR, Gyöngyi SzôLősı and Ernő BüKI (Quartz Kft.) for supporting our work for over 20 years, including having the exploratory trench excavated in 2018. This research was supported by the OTKA/NKFIH (Hungarian National Research, Development and Innovation Office) projects PD104937 and 116618, by the University of Pécs programs EFOP-3.6.1.-16-2016-00004 and 20765-3/2018/FEKUTSTRAT, and by the Bolyai János Research Scholarship of the Hungarian Academy of Sciences and the Zoltán Magyary postdoctoral grant [TÁMOP 4.2.4. A/2-11-1-2012-0001 'National Excellence Program']. The detailed reviews of László CsONTOS, Attila PETRIK and László FoDOR greatly improved the quality of the manuscript.

\section{References - Irodalom}

ANDERSON, E. M. 1951: The dynamics of faulting and dyke formation with application to Britain. - Oliver \& Boyd, Edinburgh, 2nd edition, $206 \mathrm{p}$.

Bada, G., Horváth, F., Dövényi, P., Szafián, P., Windhoffer, G. \& Cloetingh, S. 2007: Present-day stress field and tectonic inversion in the Pannonian basin. - Global and Planetary Change 58, 165-180.

Balázs, A., Matenco, L., Magyar, I., Horváth, F. \& Cloetingh, S. 2016: The link between tectonics and sedimentation in back-arc basins: new genetic constraints from the analysis of the Pannonian Basin. - Tectonics 35, 1526-1559. https://doi.org/10.1002/ 2015TC004109

BARTHA F. 1971: A magyarországi pannon biosztratigráfiai vizsgálata [Biostratigraphic investigation of the Pannonian in Hungary]. In: GócZÁn F. \& BENKő J. 1971: A magyarországi pannonkori képzódmények kutatásai [Studies in Pannonian deposits in Hungary]. Akadémiai Kiadó, Budapest, 9-172. 
Benkovics, L. 1997: Étude structurale et géodynamique des monts Buda, Mecsek et Villány (Hongrie). - Doctoral thesis, Université des Sciences et Technologies de Lille, $230 \mathrm{p}$.

Botka, D., Rofrics, N., Katona L., Magyar, I. 2021: Pannonian and Sarmatian mollusks from Pécs-Danitzpuszta, southern Hungary: a unique local faunal succession. - Földtani Közlöny 151/4, 335-362.

Csontos, L., TARI, G., Bergerat, F. \& Fodor, L. 1991: Evolution of the stress fields in the Carpatho-Pannonian area during the Neogene. -Tectonophysics 199, 73-91.

Csontos, L., Benkovics, L., Bergerat, F., Mansy, J.-L. \& Wórum, G. 2002: Tertiary deformation history from seismic section study and fault analysis in a former European Tethyan margin (the Mecsek-Villány area, SW Hungary). - Tectonophysics 357/1-4, 81-102. https://doi.org/10.1016/S0040-1951(02)00363-3

Fodor L. 2008: Szerkezetföldtan (Structural geology). In: Budai T., Fodor L., Császár G., Csillag G., GÁL N., Kercsmár Zs., Kordos L., PÁlfalvi S. \& SElmeCZI I. 2008: A Vértes hegység földtana. Magyarázó a Vértes hegység földtani térképéhez (1:50 000) (Explanatory Book to the Geological Map of the Vértes Hills [1:50 000]). Geological Institute of Hungary, Budapest, pp. 145-202. and 282-300.

FODOR L. 2010: Mezozoos-kainozoos feszültségmezók és törésrendszerek a Pannon-medence ÉNy-i részén-módszertan és szerkezeti elemzés (Mesozoic-Cenozoic stress fields and fault systems in the NW Pannonian Basin-methodology and structural analysis). DSc dissertation, Hungarian Academy of Sciences, $167 \mathrm{p}$.

FODOR, L. 2019: Results, problems and future tasks of palaeostress and fault-slip analyses in the Pannonian Basin: the Hungarian contribution. - Földtani Közlöny 149/4, 297-326. 10.23928/foldt.kozl.2019.149.4.297

Fodor, L., Csontos, L., BAdA, G., Györfi, I. \& BenKovics, L. 1999: Tertiary tectonic evolution of the Pannonian Basin system and neighbouring orogens: a new synthesis of palaeostress data. - In: Durand, B., Jolivet, L, Horváth, F. \& SÉRAnNe, M. (eds): The Mediterranean Basins: Tertiary Extension within the Alpine Orogen. Geological Society, London, Special Publications 156, $295-334$.

Fodor, L., Bada, G., Csillag, G., Horváth, E., Ruszkiczay-Rüdiger, Zs., Palotás, K., Síkhegyi, F., Timár, G., Cloetingh, S. \& Horváth, F. 2005: An outline of neotectonic structures and morphotectonics of the western and central Pannonian Basin. - Tectonophysics 410, 15-41.

Fodor, L., Balázs, A., Csillag, G., Dunkl, I., HéJa, G., Jelen, B., Kelemen, P., Kövér, Sz., Németh, A., Nyíri, D., Selmeczi, I., TrajaNOVA, M., VRABEC, M. \& VRABEC, M. 2021: Crustal exhumation and depocenter migration from the Alpine orogenic margin towards the Pannonian extensional back-arc basin controlled by inheritance. - Global and Planetary Change 201, 103475, 31 p., https://doi.org/10.1016/j.gloplacha.2021.103475

HoRvÁth, F. 1995: Phases of compression during the evolution of the Pannonian Basin and its bearing on hydrocarbon exploration. Marine and Petroleum Geology 12, 837-844. https://doi.org/10.1016/0264-8172(95)98851-U

Horváth, F. 2007: A Pannon-medence geodinamikája. Eszmetörténeti tanulmány és geofizikai szintézis (Geodynamics of the Pannonian Basin). - DSc dissertation, Budapest, 240 p.

Horváth, F., Bada, G., Szafián, P., Tari, G., ÁdÁm, A. \& Cloething, S. 2006: Formation and deformation of the Pannonian basin: Constraints from observational data. - In: GeE \& D. G., Stephenson, R. A. (eds): European Lithosphere Dynamics. Geological Society London Memoirs 32, 191-206.

JuHÁsz Á. 1987: Évmilliók emlékei [Memories of millions of years]. - Gondolat Kiadó, Budapest, 562 p.

KLEB B. 1973: A mecseki pannon földtana (Geologie des Pannons im Mecsek). - Annals of the Geological Institute of Hungary 53/3, 750-943.

KonRÁD Gy. \& SEBE K. 2010: Fiatal tektonikai jelenségek új észlelései a Nyugati-Mecsekben és környezetében (New Records of Young Tectonic Phenomena in the Western Mecsek Mts. and their Surroundings). - Földtani Közlöny 140/2, 445-468.

KonRÁd Gy., Sebe K., Halász A. \& Halmai Á. 2010: A Délkelet-Dunántúl földtani fejlődéstörténete - recens analógiák (The major phases in the geological evolution of south-east Transdanubia and their recent analogues). - Földrajzi Közlemények (Geographical Review) 134/3, 251-265.

Magyar, I. 2021: Chronostratigraphy of clinothem-filled non-marine basins: Dating the Pannonian Stage. - Global and Planetary Change 205, 103609, 10 p., https://doi.org/10.1016/j.gloplacha.2021.103609

MAGYAR, I. \& GEARY, D. H. 2012: Biostratigraphy in a Late Neogene Caspian-type lacustrine basin: Lake Pannon, Hungary. - In: BAGANZ O. V., BARTOV, Y., BoHÁCs, K. \& NummEDAL, D. (eds): Lacustrine sandstone reservoirs and hydrocarbon systems. AAPG Memoir 95, $255-264$.

MAtEnCo, L. \& RAdivojević, D. 2012: On the formation and evolution of the Pannonian Basin: Constraints derived from the structure of the junction area between the Carpathians and Dinarides. - Tectonics 31, TC6007. https://doi.org/10.1029/2012TC003206

SEBE, K. \& MAGYAR, I. (submitted): From post-rift phase to basin inversion - late-stage tectonic evolution of the Mecsek-Villány area, SW Pannonian Basin. - Submitted to Tectonophysics.

Sebe, K., Kovačić, M., Magyar, I., Krizmanić, K., Špelić, M., Bigunac, D., Sütó-Szentai, M., Kovács, Á., Szuromi-Korecz, A., „Bakrač, K., Hajek-Tadesse, V., Troskot-Č́nbić, T. \& Sztanó O. 2020: Correlation of upper Miocene-Pliocene Lake Pannon deposits across the Drava Basin, Croatia and Hungary. - Geologia Croatica 73/3, 177-195. https://doi.org/10.4154/gc.2020.12

Sebe, K., Konrád, Gy. \& Sztanó, O. 2021: An exceptional surface occurrence: the middle to upper Miocene succession of PécsDanitzpuszta (SW Hungary). - Földtani Közlöny 151/3, 235-252.

Tomljenović, B. \& Csontos, L. 2001: Neogene-Quaternary structures in the border zone between Alps, Dinarides and Pannonian basin (Hrvatsko zagorje and Karlovac basins, Croatia). - International Journal of Earth Sciences 90, 560-578. https://doi.org/10.1007/ s005310000176

Uhrin A., Magyar I. \& SzTAnó O. 2009: Az aljzatdeformáció hatása a pannóniai üledékképződés menetére a Zalai-medencében (Control of the Late Neogene (Pannonian s.1.) sedimentation by basement deformation in the Zala Basin). - Földtani Közlöny 139/3, 273-282.

VADÁsz E. 1960: Magyarország földtana (Geology of Hungary). — Akadémiai Kiadó, Budapest, 646 p.

Kézirat beérkezett: 11/05/2021 